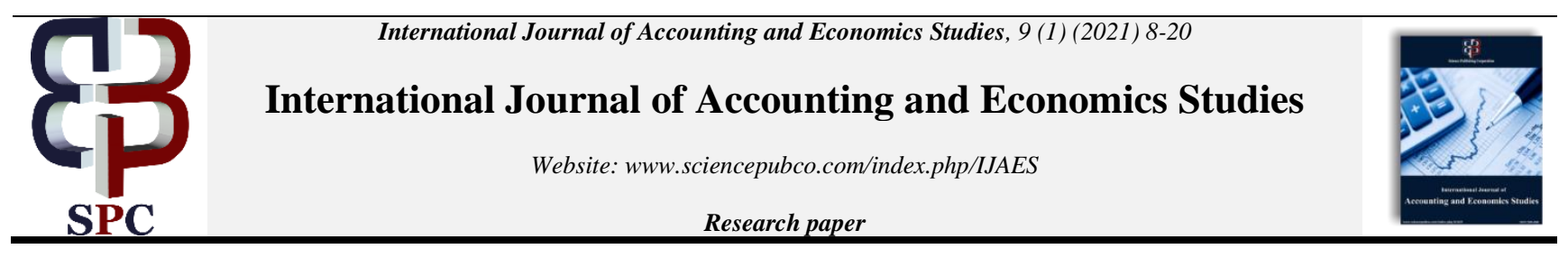

\title{
Carbon performance, carbon disclosure, and economic performance: the mediating role of carbon (media) legitimacy in the UK
}

\author{
Alireza Rohani ${ }^{1}$ *, Mirna Jabbour ${ }^{2}$, Magdy Abdel-Kader ${ }^{3}$ \\ ${ }^{1}$ Middlesex University Business School, Middlesex University, London, UK \\ ${ }^{2}$ Sheffield University Management School, The University of Sheffield, Sheffield, UK \\ ${ }^{3}$ Faculty of Commerce, Cairo University, Egypt \\ *Corresponding author E-mail: a.rohani@mdx.ac.uk
}

\begin{abstract}
There has been a continuous and controversial debate about the relationship between carbon performance, carbon disclosure, and economic performance. This study investigates whether corporate economic performance is influenced by carbon performance and disclosure and whether carbon (media) legitimacy mediates such relationships. This study provides a broader understanding of the relationship between carbon performance, disclosure, and economic performance by investigating the mediating role of carbon (media) legitimacy, and offers further evidence from the UK context. Based on a balanced panel data of 95 UK firms between 2009 and 2014 (amounting to 475 observations in total) and using path analysis, we find that improving the company's carbon performance is not financed by shareholders, and carbon (media) legitimacy as an intangible asset enhances the economic performance of the firm. We also find that while carbon disclosure does not directly improve economic performance, it indirectly does so via carbon (media) legitimacy. Finally, the results show while carbon performance is not reflected in carbon (media) legitimacy, carbon disclosure as a legitimizing tool strongly enhances carbon (media) legitimacy. Overall, our results suggest that voluntary carbon disclosure, regardless of the firm's underlying carbon performance, is an effective tool to manage corporate (media) legitimacy, and subsequently improve economic performance. Thus, voluntary carbon disclosure in the UK may hinder future improvements in a firm's carbon performance.
\end{abstract}

Keywords: Carbon Performance; Carbon Disclosure; Carbon (Media) Legitimacy; Economic Performance; Legitimacy Theory

\section{Introduction}

Social and political concerns have been raised regarding carbon footprint-related issues over the past decade, which were reflected in the introduction of carbon tax and carbon offset schemes, growth in emissions trading, voluntary initiatives such as Carbon Disclosure Project, and so forth (Hrasky, 2011). Stakeholders (e.g. customers/clients, investors, governments, etc.) are also increasingly pressurizing firms to manage/monitor and disclose their carbon emissions. In response to such pressures, corporations are trying to reduce their emissions, develop different strategies, and take varied actions such as voluntary carbon disclosure (Li et al., 2018). However, companies showed slow responses with effective action. 'Many firms are failing to reduce their absolute greenhouse gas emissions, which contribute to climate change' (Slawinski et al., 2015, p. 253). This may indicate that companies are not inclined to engage in climate change mitigation due to the belief that it does not pay to be green. However, the negative effect of poor carbon performance on the share price has been evident in many cases.

In this study, we investigate how corporate economic performance is affected by carbon performance and carbon disclosure, and how carbon (media) ${ }^{1}$ legitimacy mediates such a relationship. We argue that not only carbon performance and disclosure may directly affect firm's economic performance, but also they may indirectly do so through enhancing carbon legitimacy. Prior studies asserted that environmental legitimacy can be a key informal driver of carbon disclosure (Hrasky, 2011; Luo et al., 2012). However, researchers investigating this relationship (see, Li et al., 2018) have not considered the potential reverse association between carbon disclosure (or performance) and carbon legitimacy. This relationship merits attention because, from a resource-based view perspective, legitimacy as a valuable intangible asset can enhance firms' economic performance. The key concern is that if companies enhance their legitimacy and subsequently economic performance via voluntary carbon disclosure regardless of their underlying carbon performance, they might have less incentive to improve their underlying carbon performance in the future. As such, voluntary disclosure might be used in a superficial manner (Cho et al., 2012), and may hinder future improvements in corporate carbon performance. Hence, investigating the mediating role

\footnotetext{
${ }^{1}$ We view carbon legitimacy to be grounded in the public media role in constructing social perception (Aerts and Cormier, 2009). According to Aerts and Cormier $(2009$, p.3) 'as institutional intermediaries specializing in disseminating information about organizations or in evaluating their outputs, public media play an important role in legitimation processes'.
} 
of carbon legitimacy in the relationship between carbon performance, disclosure and economic performance within a single inclusive model becomes pivotal to address such concern.

In this study, we build on legitimacy theory. Legitimacy theory assumes that companies may be motivated to employ voluntary disclosures as a legitimation strategy to gain, maintain and/or repair corporate legitimacy. The resource-based view of legitimacy assumes that companies with more engagement in carbon and climate change activities are likely to enjoy better legitimacy and subsequently better economic performance. This is due to legitimacy being a strategic resource, which helps companies to avert sanctions/punishments resulting from a decrease in customer base, and/or limited labor and/or access to capital resources from society (Deegan and Unerman, 2011). Moreover, corporate legitimacy is characterized as an intangible asset, which possibly offers organizations a competitive advantage that could lead to improved profitability. The application of this theoretical perspective to the carbon context can help in exploring not only the pairwise relation between carbon performance, disclosure, and economic performance (as examined by the existing accounting literature), but also the multilateral relations by looking at the role of carbon legitimacy in this important context.

To achieve our aim, a sample of 95 UK companies from FTSE350, which consistently reported their carbon emission to CDP ${ }^{2}$ from 2009 to 2014 (total of 475 observations) were selected. The start of this period witnessed a rise in the concerns about climate change, and managers began to realize the urgency of managing climate change as carbon management activities/innovation were encouraged by introducing market incentive schemes (e.g. European Union ETS) (Hörisch, 2013). The CDP is argued to be the largest database of carbon emissions data (Green and Zhou, 2013), which provides consistent carbon information for all participating firms (Luo and Tang, 2014) due to the existence of a set of norms to be followed (Datt et al., 2019). The UK represents an interesting context for our study because it is seen as a leading country in tackling climate change and global warming. The UK government has consistently developed various schemes and acts as a way to promote environmentally friendly strategies (Abdel-Maksoud et al., 2020). As such, FTSE100 companies have increasingly engaged in actions to reduce GHG emissions (Okereke, 2007). In addition, the extent of implementing corporate social responsibility reports (CSR) has increased since 2013, which shows an obligation to report emissions by companies listed on the London Stock Exchange (KPMG, 2013). Nevertheless, the heart of the issue is argued to be not addressed by UK companies and government policies (Luo and Tang, 2014). The level of emissions reduction strategies implementation is argued to be low and largely differs among sectors in the UK (Renukappa et al., 2013). Companies listed on FTSE350, as the biggest polluters in the UK, have shown commitment toward carbon transparency and carbon reduction by, for instance, participating in the Carbon Disclosure Project (CDP) survey every year. However, they are still argued to be far from achieving a real reduction in carbon emissions (Luo and Tang, 2014).

Our findings show that improving the company's carbon performance is not financed by shareholders, and carbon (media) legitimacy as an intangible asset enhances the economic performance of the firm. They also report that voluntary carbon disclosure can be an effective tool to manage corporate (media) legitimacy. Overall, our results suggest that voluntary carbon disclosure, regardless of its quality and firm's underlying carbon performance, enhances economic performance via carbon (media) legitimacy. Such results, which may not be considered good news for proponents of climate change, imply that voluntary carbon disclosure may hinder future improvement in a firm's carbon performance.

Our study has two key contributions. First, it extends prior empirical research via investigating the indirect effect of carbon performance and carbon disclosure on economic performance via carbon (media) legitimacy. Accounting researchers examined the pairwise/direct relation between carbon performance and financial performance (Busch and Hoffmann, 2011; Delmas and Nairn-Birch, 2011; Iwata and Okada, 2011; Hatakeda et al., 2012; Wang et al., 2014; Rokhmawati et al., 2015; Liu et al., 2016; Rokhmawati and Gunardi, 2017), carbon disclosure and financial performance (Kim and Lyon, 2011; Matsumura et al., 2014; Saka and Oshika, 2014; Lee et al., 2015;), and carbon disclosure and carbon performance (Hassan and Kouhy, 2014; Luo and Tang, 2014; Giannarakis et al., 2017;). Despite the limited number of studies addressing the association between those constructs in the academic literature (Liu et al., 2016), no study has addressed both direct and indirect relationships (via carbon (media) legitimacy) between these constructs within a single inclusive model. Second, our study uses the UK as a context. Although a very limited number of studies focused on climate change in the UK context (see, Renukappa et al., 2013; Giannarakis et al., 2017; Haque, 2017), to our knowledge, no prior studies addressing the relationships between carbon performance, carbon disclosure, and economic performance used the UK as a context.

The remainder of this paper is organized as follows. Section 2 defines the conceptual framework and develops the hypotheses of this study. Section 3 illustrates the research design, sample, and variables' measurement. Section 4 presents the results and further analyses. Discussion and conclusion are presented in the last section of this paper.

\section{Conceptual framework and hypotheses development}

\subsection{Carbon performance and economic performance}

Financial consequences of environmental performance have been investigated by researchers for decades (Margolis et al., 2009). There is a common assumption by managers that engagement in environmental-related practices can be associated with large costs impacting profit. If profit maximization and environmental activities happen simultaneously, addressing environmental matters would not be controversial. Overall, the results of 40 years of empirical research (Günther et al., 2012) showed a positive but weak relationship between environmental performance and financial performance (Russo and Minto, 2012).

Recently, researchers have shown an increasing interest in addressing issues related to greenhouse gas (GHG) emissions because of their impact on climate change (Jones et al., 2017). Such concerns motivated a number of accounting researchers to examine the effect of GHG emissions on firm financial performance. Those studies yielded mixed results (Busch and Hoffmann, 2011; Delmas and Nairn-Birch, 2011; Iwata and Okada, 2011; Hatakeda et al., 2012; Wang et al., 2014; Rokhmawati et al., 2015; Rokhmawati and Gunardi, 2017).

Gallego-Alvarez (2012) examined the effect of GHG emission variations (2006-2007) on firm performance in four-time periods ( $t, t+1, t$ +2 and $t+3)$, measuring firm performance using ROE and ROA. Their results showed a significant negative relationship between the variation in GHG emissions and ROA in 2007 only, while a non-statistically relationship is observed for the rest of the years for ROE and ROA. Ngwakwe and Msweli (2013) examined the effect of the carbon emission reduction program of a single case company on its financial performance. The data was collected from the company's 2011 Sustainability Report. The findings indicated that carbon reduction significantly improved financial performance. Wang et al. (2014) examined the effect of GHG emissions on the financial performance of

2 The CDP is a not-for-profit organization holding the largest database of self-reported climate data from the world's largest companies. On yearly basis, companies provide information on their carbon emissions, energy use, risk and opportunities related to climate change, and so forth by completing a survey sent out by the CDP. This information is subsequently assessed by the CDP. 
Australian companies. Using multiple regression and data from 69 Australian public companies, a positive relationship between financial performance (measured by Tobin's q) and emissions was documented. Their results are not consistent with prior research findings that are conducted in other countries. As such, the economic structure and development of a specific country can explain the type of relationship between carbon performance and financial performance. In this regard, it makes sense to investigate this relationship in the UK context. Matsumura et al. (2014) investigated the effects of carbon emissions on firm value using emissions data of S\&P 500 firms disclosed to the CDP over the period 2006 to 2008. They reported that carbon performance and firm value are positively related. Clarkson et al. (2015) examined the effect of carbon emissions on firm valuation under the European Union Carbon Emissions Trading Scheme. They used 843 firm-year observations from European Union Carbon Emissions Trading Scheme from the period 2006-2009. They found a significant negative relationship between carbon emissions reported to CDP and a firm's market capitalization. They also concluded that the valuation effect of EU carbon emissions of a firm is significantly higher than its non-EU emissions which are not subject to a cap-and-trade system. A more recent study by Lewandowski (2017) investigated the relationship between carbon performance and financial performance using an unbalanced large sample of international firms over the period from 2003 to 2015 . Carbon performance was found to be positively associated with economic performance using a nonlinear modeling technique. Carbon emission mitigation was found to be significantly positively associated with return on sales but negatively associated with Tobin's q. Such contradictory findings showed the slow response of firms with effective actions to 'tackle climate beyond marginal efficiency improvements that correspond to low-hanging fruits' (p. 1196). Thus, following prior studies, mostly documenting a positive relationship between carbon performance and economic performance, the following hypothesis is developed:

H1a: Ceteris paribus, economic performance is positively associated with carbon performance.

\subsection{Carbon disclosure and economic performance}

Compared to the investigation of the relationship between carbon performance and financial performance, examinations of the effect of carbon disclosure on financial performance are more limited (see Liu et al., 2016). The evidence of the nature of carbon disclosure influence on firm performance is reported as ambiguous in a recent literature review conducted by Hahn et al. (2015). As such, 'the effects of carbon disclosure represent a major gap that should be filled by future research' (Hahn et al., 2015, p. 97). This is crucial because the public debate is dominated by the view that increased carbon disclosures positively impact corporations and the environment. However, the existing body of literature provides mixed evidence on such a relationship (Hahn et al., 2015, p. 97).

Kim and Lyon (2011) investigated whether and how emissions disclosures influence stock prices of the Financial Times Global 500 companies as a result of participating in the CDP project. The authors found no evidence that shareholder value is improved by CDP participation. But, when the Kyoto Protocol went into effect (regulation), participation in the CDP increased the company's stock prices. Matsumura et al. (2014) examined the impact of the act of voluntary disclosure of carbon emissions on firm value. The findings indicated that the markets penalize companies that do not disclose information on their emissions. Saka and Oshika (2014) also examined the effect of carbon disclosure on corporate value using a sample of Japanese companies (more than 1,000). Similar to Kim and Lyon (2011), companies' responses to CDP were used as a proxy for carbon disclosures. A positive relation was reported between carbon disclosure and the market value of equity.

Lee et al. (2015) examined the responses of the market to corporate voluntary carbon disclosure, as well as the moderating impact of carbon communication on the link between carbon disclosure and shareholder value. Using a sample of companies from the CDP Korea (20082009), the authors found a negative market response to corporate carbon disclosure. As such, carbon disclosure is perceived as bad news by investors. It was also suggested that the negative market response to disclosure could be mitigated through the release of periodical carbon news through the media prior to the carbon disclosure, which confirms the effect that media can have on stakeholders' perceptions. A more recent study by Liu et al. (2016) examined how carbon disclosure mediates the relation between carbon performance and financial performance (market-based financial performance). The findings showed a positive relationship between carbon emission and carbon disclosure level, which significantly and positively impacts financial performance. It was found that 'companies with poor carbon performance tend to use disclosure strategically to manage the legitimacy threat and to reduce the information asymmetry' (Liu et al., 2016, p. 1).

Accordingly, following prior studies, mostly documenting a positive relationship between these two constructs, and given the growing climate change concern amongst stakeholders, the following hypotheses are developed:

H1b: Ceteris paribus, economic performance is positively associated with carbon disclosure.

\subsection{Carbon (media) legitimacy}

We further argue in this study that carbon performance and carbon disclosure may indirectly improve economic performance through corporate carbon legitimacy. From a resource-based view perspective of legitimacy, legitimacy as a strategic resource (Deegan and Unerman, 2011) is a valuable intangible asset because it enhances corporate competitive advantage.

We view carbon legitimacy to be grounded in the media's role in the construction process of social perception. The content of media is found to be aligned with public opinion 'as part of agenda-setting and framing paradigms' (Deephouse and Carter, 2005, p. 339). Aerts and Cormier (2009) argued that media evaluations could be viewed as the single persistent proxy for collective impressions of legitimacy. Hence, public media could play an important role in the legitimation process because it is viewed as an institutional intermediary that disseminates information about organizations or evaluates their outputs (Fombrun, 1996).

Climate change has been one of the main topics in society. Reports on the recent scientific insights and natural disasters could foster a public opinion that urgent counter-measures are needed. In this regard, managing climate change in a proactive manner matters to powerful stakeholders and thus is clearly linked to the level of a company's legitimacy (Busch and Hoffmann, 2011). Both carbon performance and voluntary carbon disclosure could affect (media) legitimacy. The carbon-related information reported in the media comes or is influenced by many sources such as companies' disclosures, government and/or NGOs such as Carbon Disclosure Project (CDP). Also, the media offer information to stakeholders (e.g. customers, clients, investors, etc.). Not all stakeholders have direct experiences with a company and thus depend on the information provided by intermediaries, such as media (Deephouse, 2000). Public media is closely followed because it is believed to have a better evaluation of, and accessibility to companies' information and its dissemination because of its institutional role or structural position (Fanelli and Misangyi, 2006). Hence, companies with a good media legitimacy can attract more customer, clients, and/or investors, which result in better economic performance. Enhanced (media) legitimacy may also help companies to avert sanctions/punishment in the form of consumer decreasing, limited labor and/or limited access to capital resources (Deegan and Unerman, 2011), 
reduction in talented and committed personnel (Castelo Branco and Rodrigues, 2006), and reduction in prospective claimants (Sharfman and Fernando, 2008).

Thus, based on the above discussion and consistent with the prediction of the resource-based view of legitimacy, we expect that companies with more engagement in carbon and climate change activities (e.g. investing in new machinery, disclosing carbon information, etc.) are likely to enjoy better (media) legitimacy and subsequently enjoy a better economic performance. Hence, the following hypothesis is developed:

H2a: Ceteris paribus, economic performance is positively associated with carbon (media) legitimacy.

In a normative sense, carbon (media) legitimacy should be based on corporate underlying carbon performance. According to Deephouse and Carter (2005), legitimacy reflects the consistency of organizational performance with social norms and values. Bansal and Clelland (2004) contended that legitimacy refers to the assumption claiming that a company's performance is desirable, proper, and/or appropriate. Qian and Schaltegger (2017) also asserted that, from a legitimacy perspective, a company's activities should correspond to its society's norms and values. The BP oil spill in 2010 and Volkswagen manipulated emission tests in 2015 provide examples of the link between poor environmental performance and potential corporate legitimacy damage. Hence, firms with a better carbon performance are expected to enjoy a more positive carbon (media) legitimacy. Thus, the following hypothesis is developed:

$\mathrm{H} 2 \mathrm{~b}$ : Ceteris paribus, carbon (media) legitimacy is positively associated with carbon performance.

From a legitimacy theory perspective, the economic legitimacy 'is monitored through the marketplace', while 'social legitimacy is monitored through the public policy process' (Patten, 2002, p. 767). When social legitimacy is suspected/threatened, companies tend to engage in the policy process. Disclosure in financial reports is one way of doing that (Patten, 2002).

Woodward et al. (1996) argued that companies could manipulate legitimacy through implementing voluntary social and environmental disclosure. This action can ultimately affect a firm's image (positively or negatively) because of the extent of that disclosure; perhaps without much consideration of the actual developments made. Thus, legitimacy is not only gained/maintained via actual companies' operations but also the way such operations are collectively perceived by society (Deegan, 2002). In this regard, Deegan (2002) contends that voluntary social and environmental disclosure can be used as a mechanism to inform society about actual changes taken by the company and/or manipulate perceptions to mitigate threats to corporate legitimacy.

Lindblom (1994) (c.f. Gray et al. 1995, p. 54) argued that disclosure could be used as a legitimizing tool to convey the company's performance and practices to the general relevant public, change their perceptions (not behaviors), and/or manipulate perceptions via diverting the attention away from the issue of concern. According to Cho and Patten (2007) and Cho et al. (2012), consistent with legitimacy theory, companies tend to utilize disclosure as a legitimation tool to minimize the negative effect of actual performance information, and hence mitigate the social and political pressures.

Based on the above discussion and consistent with legitimacy theory, we argue that companies disclosing more carbon-related information would enjoy a more positive carbon legitimacy. Thus, the following hypothesis is developed:

$\mathrm{H} 2 \mathrm{c}$ : Ceteris paribus, carbon (media) legitimacy is positively associated with carbon disclosure.

\subsection{Carbon performance and carbon disclosure}

Several studies (e.g. Hughes et al., 2001; Patten, 2002; Cho and Patten, 2007; Clarkson et al., 2011; Cho et al., 2012; Meng et al., 2014) investigated the relationship between a firm's environmental performance and environmental disclosure over the last two decades. Although their results have been mixed, they mostly documented a negative association between environmental performance and environmental disclosure. This means that the worst environmental performers disclose more environmental information in their 10-K, annual, and/or sustainability reports. For example, Patten (2002), using a sample of 131 US companies' annual reports, examined the relationship between environmental disclosure and performance. A significant and negative association between disclosure and performance was documented. Recently, there has been a shift towards addressing issues related to carbon. Several studies (e.g. Cotter and Najah, 2012; Luo et al. 2012; Luo et al., 2013; Liao et al., 2014) investigated the motivations toward voluntary carbon disclosure. For example, social, economic, and institutional pressures, the attitude of the public and government, and financial resources constraints were found to be key determinants of carbon disclosure (Luo et al., 2012; Luo et al., 2013). The importance of carbon information has heightened in stakeholders' decisionmaking process. However, the reliability of corporate carbon disclosure has been questioned (i.e. whether or not such disclosure truly reflects a firm's underlying carbon performance), particularly when only a limited number of studies addressed this issue (Luo and Tang, 2014).

Hassan and Kouhy (2014) examined the relationship between carbon disclosure and performance in the Nigerian oil and gas industry. Carbon performance was measured using the Data Development Analysis. Content analyses of companies' annual reports, press releases, and fact sheets were used to measure the substance and volume of the disclosure. They reported that disclosure substance is significantly and negatively associated with performance. In contrary to most prior research, Luo and Tang (2014) documented a significant positive relationship between carbon disclosure and carbon performance using 474 U.S., U.K., and Australian companies. This suggests that actual carbon performance is reflected in the CDP voluntary disclosure. Their result is consistent with the signaling theory. A more recent study by Giannarakis et al. (2017) focused on whether climate change disclosure reflects corporate carbon performance. Using a sample of 119 UK firms listed on FTSE 350, they reported that carbon performance is positively related to climate change disclosure.

Clearly, the relationship between carbon performance and carbon disclosure is still an unresolved issue in the environmental accounting domain. The above debate calls for further studies addressing whether carbon disclosure reflects the underlying carbon performance to provide evidence on whether the information disclosed is useful (or not) for stakeholders, and relevant for evaluating companies' carbon exposure risk, climate change-related commitment, and reductions in GHG emissions. The existing conflicting results are argued to fail to theorize the link between carbon disclosure and performance systematically (Luo and Tang, 2014).

Following Patten (2002), we argue that companies with poorer carbon performance would be more exposed to potential public and regulatory scrutiny, and may face threatened legitimacy. Based on the legitimacy-based arguments, if corporate legitimacy is threatened by poorer carbon performance, companies report more information to maintain their legitimacy and mitigate public pressures. Hence, the following hypothesis is developed:

H3: Ceteris paribus, carbon disclosure is negatively associated with carbon performance. 


\section{Research design, sample selection, and variables' measurement}

\subsection{Research design}

Consistent with the study by Aerts and Cormier (2009), our study uses a time sequence design to improve the interpretability of casual relationships with variables. We argue that since carbon information disclosed in annual and/or sustainability reports, and carbon emissions provided by CDP are available at the end of the year, the effects of carbon disclosure and carbon performance are not reflected in carbon legitimacy and economic performance in the same year. Therefore, we use carbon performance and carbon disclosure measures at t-1 (i.e. 2009-2013), and carbon legitimacy and economic performance measures at t (i.e. 2010-2014). Fig. 1 represents this study's theoretical model and variables.

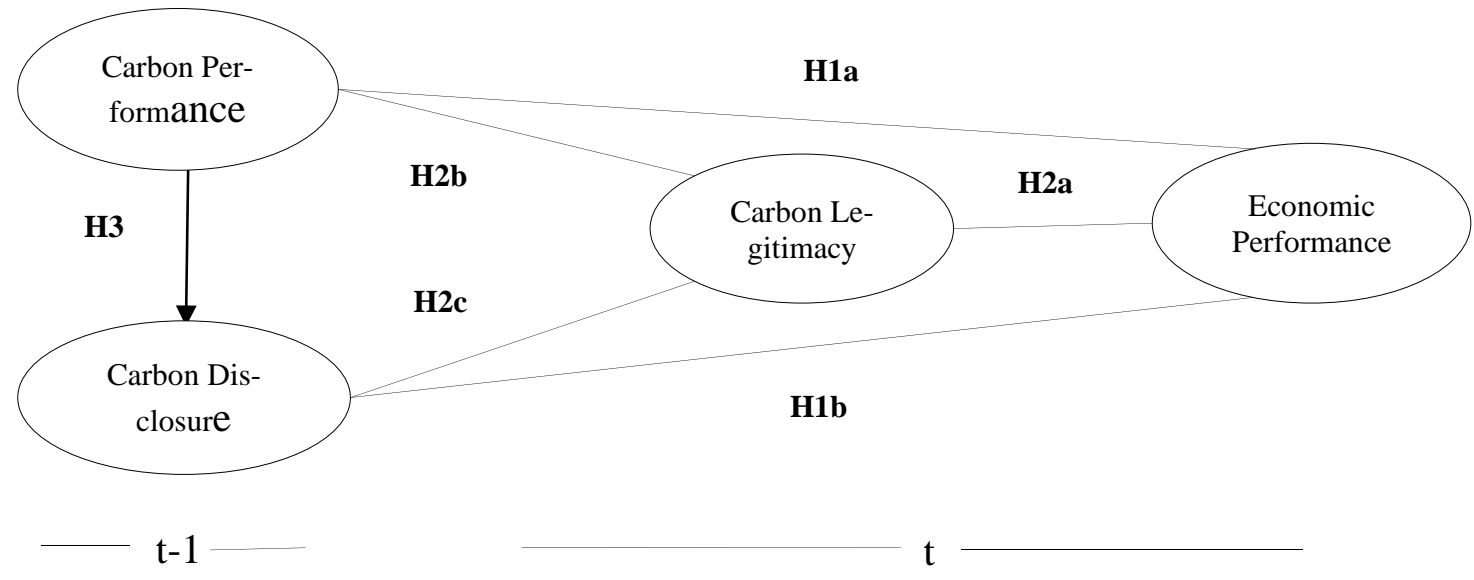

Fig. 1: Theoretical model.

Our study hypothesized relations are interconnected. To test the hypotheses, we use path analysis to test both direct and indirect relationships between variables. An overall structural model is estimated (not a measurement one) because the variables of this study are observed variables that are directly measured. In addition, balanced panel data has been used to test the hypothesized relationship of the current study. Balanced data allows observation of the same unit in every time period which reduces the noise introduced by unit heterogeneity.

\subsection{Sample}

The initial sample of the current study contains all UK FTSE350 companies where it is argued that their climate change issues are salient (Liao et al., 2015). However, only 95 companies have been selected because these companies have consistently reported their carbon emission to CDP over the period of investigation ${ }^{3}$. As aforementioned, balanced panel data reduces the noise introduced by unit heterogeneity. Therefore, the final sample included 475 company-years observations. Over the period under study (i.e. 2009-2014), managers gradually realized the urgency of managing climate change since corporate carbon management activities and innovation were encouraged by introducing market incentive schemes such as European Union ETS (Hörisch, 2013).

It is argued that it is difficult to define when the 'age' of a sample within a given paper is 'old', particularly because of the time required to do the research and present it at conferences or workshops. This may lead to the belief that the paper was not updated. However, "an 'old' sample would be considered acceptable if the paper is based on data that date from several years ago but for which the phenomenon being studied is still of current interest" (Stolowy, 2017, p. 415). Since carbon disclosure has largely remained voluntary in the UK ${ }^{4}$, the concern of this study remains unchanged that if voluntary carbon disclosure, regardless of the firm's underlying carbon performance, can improve carbon (media) legitimacy and subsequently economic performance, it may hinder future improvements in corporate carbon performance. In this regard, the age of the data in our study should not impose any concerns; and data inferences are considered to be appropriate.

\subsection{Variables' measurement}

\subsubsection{Carbon performance}

For the aim of this study carbon performance (emissions relative to economic output) is measured as the ratio of total direct (Scope 1) and indirect (scope 2) 5 emissions obtained from CDP over the period from 2009 to 2013 to total sales ( Patten, 2002; Clarkson et al., 2008; Luo

\footnotetext{
${ }^{3} \mathrm{CDP}$ data have been used to measure firms' carbon performance. As aforementioned, CDP has the most comprehensive carbon emission database in the world and CDP data have been increasingly used by several previous studies over the last years (e.g. Kim and Lyon, 2011; Luo et al., 2012; Qian and Schaltegger, 2017).

${ }^{4}$ It is worth mentioning that Companies Act Regulations 2013 requires companies to state in their reports the "annual quantity of emissions in tons of carbon dioxide equivalent from activities for which that company is responsible" (Article 465) (i.e. mainly numerical information). Our measure of carbon disclosure in this study captures non-numerical information provided by companies in sustainability reports and/or annual reports. Such information, which shows companies' plans and actions to reduce their carbon emission, remains largely voluntary in the UK.

${ }^{5}$ The GHG protocol requires companies to report emissions classified into three scopes. Scope1 is the direct emissions from companies' owned/controlled sources. Scope 2 encompasses the indirect emissions from consuming purchased electricity, heat, and/or steam. Scope 3 includes the other indirect emissions, such as, waste disposal, transportation and outsources activities. As the latter emission sources differ among companies, Scope 3 was excluded.
} 
and Tang, 2014). This emission intensity ratio is more comparable across different reporting periods and between firms than the absolute level of carbon emissions as it considers the variation in the output of products and services. Furthermore, according to Patten (2002), such an adjustment for company size is made because larger firms would be expected to have higher environmental impacts than smaller firms. Since total scope1 and scope 2 reflect a firm's pollution level, carbon performance scores are inverted by multiplying them by a negative one to allow consistency with proposed hypotheses. Thus, higher scores used in the analysis indicate better carbon performance.

\subsubsection{Carbon disclosure}

Because of adopting legitimacy theory which is related to managers' incentives of voluntary disclosure, stand-alone sustainability reports as voluntary disclosure channels are used. In the absence of sustainability reports, CSR sections of the annual reports are employed.

To measure carbon disclosure, a density ratio is used to avoid unnecessary information over the period from 2009 to 2013 . Under G3.1 of the GRI guidelines, while reports should provide the level of information required by stakeholders, they out to avoid unnecessary and excessive information. Cho and Roberts (2010) asserted that diluting social and environmental information in a long document such as a stand-alone sustainability report may serve to provide relevant information, but it may divert attention as it would be challenging for the user to find the relevant information. Hence, following Michelon et al. (2015), the density of carbon-related information is measured as the ratio of the number of carbon-related sentences over the total number of sentences of the stand-alone sustainability report or the voluntary CSR section of the annual report. Sentences are more reliable than pages and words since they overcome "the problems of allocations of portions of pages remove the need to account for, or standardize, the number of words and are a more natural unit of written English to count than words' (Hasseldine et al., 2005, p.236).

\subsubsection{Carbon legitimacy}

Content analysis of newspaper articles for corporate carbon issues was used to measure carbon legitimacy. 'Public media data are the most salient and prominent source for evaluating corporate legitimacy (Cormier and Magnan 2015; DeVilliers and Van Staden 2010)' (Li et al., 2018, p. 1094). Several studies (e.g. Gamson et al., 1992; Ader, 1995; Deephouse and Carter, 2005) showed that media content and public opinion are closely aligned as part of agenda-setting and framing paradigms. According to Cormier and Magnan (2015, p. 434) 'as an institutional intermediary, focusing on dissemination and evaluation of corporate information, public media play an important role in legitimation processes'. Newspapers have a strong effect on the public's perceptions and can actively participate in the social construction processes (Palmgreen et al., 2001). Therefore, content analysis of print media can be useful in studying the legitimation process since its detailed archives are available for long periods, and offer powerful techniques for operationalizing legitimation (Baum and Powell, 1995). To measure carbon legitimacy, media coverage about corporate carbon issues is analyzed by searching and classifying related newspapers' articles. In total, 1424 articles have been extracted from Lexis Nexis ${ }^{6}$ using a companies' name and the following keywords: "greenhouse gas emissions", "air pollution", "climate change", "carbon", "CO2" and "global warming" over the period from 2010 to 2014 . Out of 1,424 newspaper articles, 965 articles belong to carbon-intensive industries, where 246 articles provide bad news, 664 provide good news, and 55 provide neutral news, and 459 newspaper articles belong to carbon non-intensive industries, where 335 articles provide good news, 89 provide bad news and 35 articles provide neutral news. For instance, if the newspapers' articles convey environmental commitment such as a reduction of greenhouse gas emission, they are classified as good news.

Following previous studies (e.g. Clarkson et al., 2008; Aerts and Cormier, 2009; Li et al., 2018), annual (media) legitimacy is captured using the Janis-Fadner coefficient of imbalance. The Janis-Fadner coefficient ranges from -1.0 to +1.0 ; a value close to 1.0 indicates a more favorable article, while a value close to -1.0 indicates a less favorable article (Li et al., 2018). The formula is as follows:

Janis-Fadner coefficient $=\left\{\begin{array}{c}\frac{\mathrm{f}^{2}-\mathrm{fu}}{\mathrm{t}^{2}} \text { if } \mathrm{f}>\mathrm{u} \\ 0 \text { if } \mathrm{f}=\mathrm{u} \\ \frac{\mathrm{fu}-\mathrm{u}^{2}}{\mathrm{t}^{2}} \text { if } \mathrm{u}>\mathrm{f}\end{array}\right.$

Where $f$ and $u$ are the total number of favorable and unfavorable articles in a given year respectively, and $t$ is the total of $f$ and $u$. Following Clarkson et al. (2008), the Janis-Fadner coefficient is set to zero for those firms with no carbon-related articles. Thus, silence in the media is interpreted as perceptions' neutrality about corporate carbon legitimacy (Clarkson et al., 2008).

\subsubsection{Economic performance}

Prior environmental studies have employed both accounting and market-based measures as a proxy of economic performance. In this study, economic performance is measured by return on equity (ROE). ROE represents returns to shareholders of common stocks and is generally considered an important financial indicator for investors (Chen et al., 2005). In line with the assumption of the resource-based view of legitimacy which perceives legitimacy as a strategic resource which may increase corporate annual return on shareholder investment, we use ROE of sample companies over the period from 2010 to 2014.

\subsubsection{Control variables}

Two key control variables are incorporated. These include firm size (Patten, 2002; Clasrkson et al., 2011), and industry (Cho and Patten, 2007; Clarkson et al., 2008; Aerts and Cormier, 2009; Clarkson et al., 2011; Cho et al., 2012) ${ }^{7}$. The use of these control variables is common

\footnotetext{
${ }^{6}$ LexisNexis provides full-text documents from over 15,000 credible resources, such as national and local newspapers.

${ }^{7}$ Please note that due to the type of measurement used in this study (lag), we do not control for regulations. This is because the adoption of the Companies Act Regulations 2013 mandates the disclosure of GHG emissions from 2014 onwards, which has taken place after our observation period concerning carbon performance and disclosure (measured from 2009-2013) (other variables are not affected by this regulation). In relation to emissions reporting, Companies Act Regulations 2013 requires companies to state in their reports the "annual quantity of emissions in tons of carbon dioxide equivalent from activities for which that company is responsible" (Article 465) (i.e. mainly numerical information). This explains the change in sustainability reports to contain more numerical content following the adoption of Companies Act Regulations 2013 (Hummel and Roetzel, 2019). It is also worth noting that the Companies Act Regulations 2013 is similar to the previous Companies Act 1985 Regulations 2005 in relation to that, companies' annual reports should include "an understanding of the development, performance or position of the business of the company, [...] information relating to environmental matters and employee
} 
in previous studies related to environmental disclosure, environmental performance, and economic performance. Several studies (e.g. Gray et al., 1995; Patten, 2002; Clasrkson et al., 2011) documented a significant relationship between a firm's size and the extent of environmental disclosure. Kalu et al. (2016) argued that according to stakeholder theory, since large-size companies have a greater impact on the environment, they are subject to greater stakeholders' expectations to disclose their environmental impact. Likewise, according to Aerts and Cormier $(2009$, p.10) 'size has been shown to be an antecedent of legitimacy'. Firm size affects the firm's visibility to the general public and tends to cause increased public scrutiny (Deephouse and Carter, 2005). There is also a consensus in the literature that larger companies are more likely to enjoy a better economic performance. Larger firms can leverage their size to secure better deals in financial as well as product or other factor markets (Mathur and Kenyon, 2008). Hence, we control for firm size by adding paths from size to carbon disclosure, carbon legitimacy, and economic performance. Firm size is measured as a log of total assets.

Apart from firm size, industry is one of the most common control variables used in studying the relationship between corporate social and environmental performance and economic performance. Following previous studies (e.g. Al-Tuwaijri et al., 2004; Cho and Patten, 2007; Clarkson et al., 2008; Aerts and Cormier, 2009; Clarkson et al., 2011; Cho et al., 2012) emphasizing the role of industry in the environmental practice of organizations and its effect on economic performance, we control for carbon-intensive industries ${ }^{8}$ by adding paths from carbonintensive industries to carbon disclosure, carbon legitimacy, and economic performance. According to CDP, energy, industrial, material, and utilities are classified as carbon-intensive industries. A dummy variable is used to designate companies from these industries where one shows that the company is in a carbon-intensive industry and zero otherwise. In total, 40 of the 95 sample companies are from carbonintensive industries.

\section{Results}

\subsection{Descriptive statistics and correlation analysis}

Table 1 provides some descriptive statistics regarding the variables of this study. Carbon legitimacy's mean for the sample firms is 0.34 meaning that, on average, media has been positive about sample firms' carbon-related activities. As expected, on average carbon-intensive industries produce more carbon dioxide compare to their total sales than non-intensive industries. Both carbon-intensive and non-intensive industries allocate, on average, the same proportion of sustainability report or CSR section of an annual report to carbon footprint-related information. Media has been slightly more positive about carbon activities of intensive industries, and non-intensive industries enjoy a better economic performance.

Table 1: Descriptive Statistics

\begin{tabular}{|c|c|c|c|c|c|c|c|}
\hline Variables & Observation & Mean & Std. Dev. & Min & Max & $\begin{array}{l}\text { Mean- } \\
\text { Carbon } \\
\text { Intensive } \\
\text { Industries }\end{array}$ & $\begin{array}{l}\text { Mean-Carbon } \\
\text { non-Intensive } \\
\text { Industries }\end{array}$ \\
\hline Carbon Performance & 475 & -430.54 & 2349.42 & -42852.05 & -1.05 & -889.58 & -96.68 \\
\hline Carbon Disclosure & 475 & 0.12 & 0.10 & 0 & 0.51 & 0.12 & 0.12 \\
\hline Carbon Legitimacy & 475 & .34 & .53 & -1 & 1 & 0.35 & 0.33 \\
\hline Economic Performance & 475 & 18.54 & 20.50 & -52.7 & 144.82 & 17.45 & 19.33 \\
\hline $\begin{array}{l}\text { Carbon } \\
\text { Industry }\end{array}$ & 475 & 0.42 & 0.49 & 0 & 1 & 1 & 0 \\
\hline Size & 475 & 9.83 & 0.77 & 8.69 & 12.23 & 9.72 & 9.91 \\
\hline
\end{tabular}

Carbon Performance is measured as total scope1 and scope 2 divide by total sales multiply by (-1).

Carbon Disclosure is measured as density ratio which is the number of carbon-related sentences over the total number of sentences of the stand-alone sustainability report or the voluntary CSR section of the annual report.

Carbon Legitimacy is measured using the Janis-Fadner coefficient, based on the proportion of favorable and unfavorable news articles published between 2010 and 2014

Economic Performance is measured as ROE.

Carbon Intensive Industries is coded as " 1 " if a member of carbon intensive industries, 0 otherwise.

Size is measured by $\log$ (total assets).

Table 2 presents the correlations between the variables of this study. While carbon performance $(\beta=-0.0004, p=0.99)$ is negatively correlated with economic performance and the correlation is not significant, carbon disclosure $(\beta=0.082, p<0.10)$ positively and significantly correlated with economic performance. Carbon performance is negatively correlated with carbon disclosure $(\beta=-.011, p=$ .81). The negative correlation is consistent with previous studies (e.g. Cho et al., 2012; Cho and Patten, 2007; Clarkson et al., 2011; Hughes et al., 2001; Patten, 2002), and with legitimacy theory perspective that firms with the worst environmental performance provide more environmental disclosure. Carbon disclosure $(\beta=0.152, p<0.01)$ is positively and significantly correlated with carbon legitimacy. This is consistent with legitimacy theory that companies employ voluntary disclosure as a legitimation tool. Finally, correlation between carbon legitimacy and economic performance $(\beta=0.099, p<0.05)$ is positive and significant. This is consistent with resource base view of

matters". As such, "the changes between the prior regulation and the SR [the Companies Act Regulations 2013] Regulations particularly relate to the additional disclosure on GHG emissions and the gender break" (Hummel and Roetzel, 2019, p. 211).

8 The variable carbon-intensive industry is binary ("0" or "1"). The use of a binary variable in path analysis does not violate assumptions of multivariate normality of path analysis as long as the variable has relatively small kurtosis and skewness, which has been defined as less than 1.5 (Schumacker and Lomax, 2004), or less than 2 for skewness and 7 for kurtosis (West et al., 1995). As the skewness of carbon-intensive industry is 0.32 and its kurtosis is 1.10 , the use of the variable does not appear to violate the assumptions of multivariate normality and is appropriate for use in path analysis. Furthermore, none of the other variables violates normality assumptions. 
legitimacy which perceives legitimacy as a resource which is vital for companies' survival. Table 2 indicates that all the correlation coefficients are lower than 0.630, showing an acceptable level of multicollinearity (Anderson et al., 2013).

Table 2: Correlations

\begin{tabular}{|c|c|c|c|c|c|c|}
\hline & $\begin{array}{l}\text { Carbon } \\
\text { Performance }\end{array}$ & $\begin{array}{l}\text { Carbon } \\
\text { Disclosure }\end{array}$ & $\begin{array}{l}\text { Carbon } \\
\text { Legitimacy }\end{array}$ & $\begin{array}{l}\text { Economic } \\
\text { Performance }\end{array}$ & $\begin{array}{l}\text { Carbon Intensive } \\
\text { Industries }\end{array}$ & Size \\
\hline Carbon Performance & 1 & & & & & \\
\hline Carbon Disclosure & -0.011 & 1 & & & & \\
\hline Carbon Legitimacy & 0.047 & $0.152 * * *$ & 1 & & & \\
\hline Economic Performance & -0.0004 & $0.082 *$ & $0.099 * *$ & 1 & & \\
\hline Carbon Intensive Industry & $-0.167 * * *$ & 0.001 & 0.019 & -0.045 & 1 & \\
\hline Size & 0.036 & -0.057 & -0.032 & $-0.186 * * *$ & $-0.122 * * *$ & 1 \\
\hline
\end{tabular}

Carbon Performance is measured as total scope1 and scope 2 divide by total sales multiply by (-1).

Carbon Disclosure is measured as density ratio which is the number of carbon-related sentences over the total number of sentences of the stand-alone sustainability report or the voluntary CSR section of the annual report.

Carbon Legitimacy is measured using the Janis-Fadner coefficient, based on the proportion of favorable and unfavorable news articles published between 2010 and 2014.

Economic Performance is measured as ROE.

Carbon Intensive Industries is coded as " 1 " if a member of carbon intensive industries, 0 otherwise.

Size is measured by $\log$ (total assets).

* Correlation is significant at the $\mathrm{p}=.10$ level.

** Correlation is significant at the $\mathrm{p}=.05$ level.

$* * *$ Correlation is significant at the $\mathrm{p}=.01$ level.

\subsection{Internal consistency for carbon legitimacy}

Since newspapers' articles have been collected manually and the coding process may be influenced by personal judgment, 100 newspaper articles have been randomly allocated to one of our colleagues to test internal consistency. Out of 100 articles, we agreed on $84 \%$ bad news, $83 \%$ good news, and 93\% neutral news. The variance between the two coders' scores is quite systematic based on Cronbach's alpha (measure of internal consistency) (alpha $=0.915$ for bad news, 0.891 for good news, and 0.852 for neutral news) implying a high level of intercoder reliability (Weber, 1990).

\subsection{Hypotheses testing}

We use path analysis diagram to present our results. Fig. 2 presents a path analysis of hypothesized relations using carbon performance, carbon disclosure, carbon legitimacy, and economic performance ${ }^{9}$. The model also includes firm size and carbon-intensive industries as control variables. For the aim of this study, path analysis has an advantage over multiple regression analysis. Since the hypothesized relationships of this study are interconnected, the direct and indirect relationships between all variables of interest can be tested using path analysis.

All indices demonstrate that the path model has an acceptable fit. The root-mean-square error of approximation (RMSEA) is 0.000 which is well under the recommended threshold of .08 (Hair Jr et al., 2009). The SRMR values .000 which is also well under the recommended threshold of 0.08 (Hu and Bentler, 1999). The TLI of 1, which is greater than the acceptable threshold of 0.90, also indicates a strong model fit. Finally, the CFI of 1 exceeds the recommended threshold of 0.90 (Hair Jr et al., 2009).

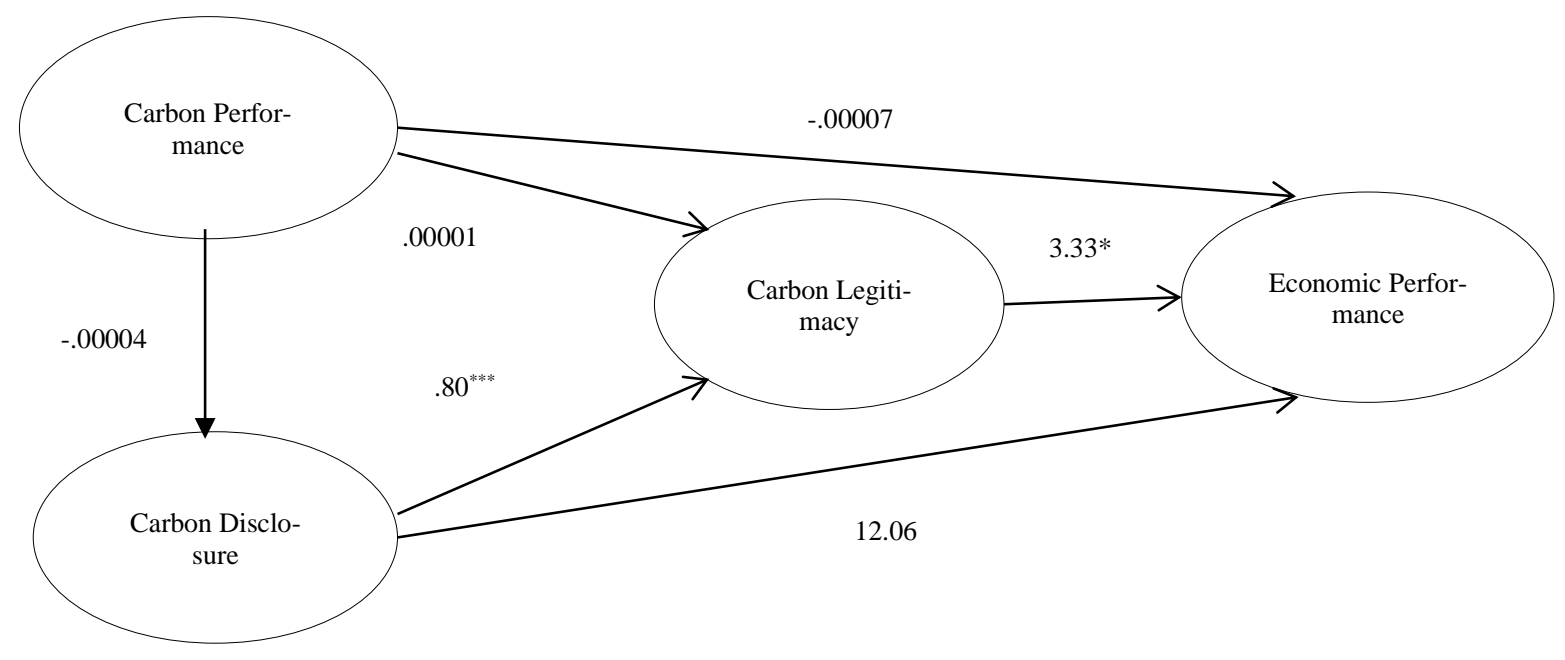

\begin{tabular}{|l|}
\hline Model Fit Statistics \\
RMSEA, .000 \\
SRMR, .000 \\
CFI, 1 \\
TLI, 1 \\
\hline
\end{tabular}

$$
\begin{aligned}
& \text { Probability Level } \\
& { }^{* * *}, p<0.01 \\
& { }^{* *}, p<0.05 \\
& *, p<0.10
\end{aligned}
$$

Fig. 2: Path Analysis of Hypothesized Relations.

\footnotetext{
${ }^{9}$ We utilized the Stata to estimate the paths.
} 


\subsubsection{Test of H1a and $\mathrm{H} 1 \mathrm{~b}$}

The first two hypotheses investigate whether carbon performance and carbon disclosure are associated with economic performance. As shown in Fig. 2 , the paths from carbon performance $(\beta=-.00007$ and $p=.84)$ and carbon disclosure $(\beta=12.06$ and $p=.19)$ to economic performance is not statistically significant. Thus, H1a and $\mathrm{H} 1 \mathrm{~b}$ are not supported. Although the results did not support both hypotheses, a non-significant relationship between carbon performance and economic performance shows that acting in an environmentally responsible way and investing in emissions abatement technologies do not harm a firm's economic performance. Also, non-significant relationship between carbon disclosure and economic performance indicates that stakeholders (e.g. customers, clients, etc) neither value nor penalize companies' carbon disclosure.

\subsubsection{Test of $\mathrm{H} 2 \mathrm{a}, \mathrm{H} 2 \mathrm{~b}$, and $\mathrm{H} 2 \mathrm{c}$}

The second sets of hypotheses relate to carbon (media) legitimacy. H2a posits a positive relationship between carbon (media) legitimacy and economic performance. As indicated in Fig. 2, the path from carbon legitimacy to economic performance is positive and statistically significant $(\beta=3.33$ and $p<.10)$. Therefore $\mathrm{H} 2 \mathrm{a}$ is supported. Such finding is consistent with the resource-based view of legitimacy which perceives legitimacy as resources (or a way to achieve resources) from which organizations are dependent for survival.

$\mathrm{H} 2 \mathrm{~b}$ and $\mathrm{H} 2 \mathrm{c}$ investigate the extent to which carbon performance and carbon disclosure are reflected in firms' carbon legitimacy. While the path from carbon performance to carbon legitimacy is not significant $(\beta=.00001$ and $p=.24)$, the path from carbon disclosure to carbon legitimacy is positive and strongly statistically significant $(\beta=.80$ and $p<.01)$. Therefore $\mathrm{H} 2 \mathrm{~b}$ is rejected and $\mathrm{H} 2 \mathrm{c}$ is supported. Interestingly our findings suggest that while underlying carbon performance is not reflected in carbon (media) legitimacy, carbon disclosure as a legitimizing tool strongly enhances carbon (media) legitimacy.

\subsubsection{Test of $\mathrm{H3}$}

As shown in Fig. 2, the path from carbon performance to carbon disclosure is negative but not statistically significant $(\beta=-.00004$ and $p$ $=.83$ ). Thus, $\mathrm{H} 3$ is not supported. Although $\mathrm{H} 3$ is rejected, the non-significant relationship between carbon performance and carbon disclosure can still be consistent with the premises of legitimacy theory. Luo and Tang (2014) argued that a non-significance relationship between carbon performance and carbon disclosure implies that companies provide such information to gain and/or maintain their legitimacy irrespective of their real carbon performance.

Since no significant relationship was found between carbon performance and economic performance as well as carbon disclosure and economic performance, we test the mediating effect that carbon legitimacy may play on the relationships between carbon performance, carbon disclosure, and economic performance. As discussed, both carbon performance and carbon disclosure may indirectly (via carbon (media) legitimacy) improve economic performance.

\subsection{Mediation tests (Indirect effects)}

Whilst the results did not support an indirect relationship between carbon performance and economic performance through legitimacy, they showed strongly statistically significant indirect relationship between carbon disclosure and economic performance $(\beta=2.69$ and $p<$ .01). In other words, the results showed that carbon (media) legitimacy significantly mediates the relationship between carbon disclosures and economic performance. The findings indicated that while stakeholders (e.g. customers, clients, etc.) do not directly value carbon disclosures, such disclosures by improving media legitimacy can manage stakeholders' perception, and hence enhance economic performance. Thus, our findings are contrary to the desires of proponents of improved corporate carbon performance, since such disclosure may hinder the actual improvement in underlying carbon performance. In other words, as long as such disclosure (irrespective of corporate carbon performance) can improve (media) legitimacy and subsequently economic performance, there is less incentive for managers to reduce the level of carbon emission.

\subsection{Sensitivity test}

Since density ratio merely measures the quantity of carbon disclosure, we repeat our path analysis using quality of carbon disclosure. Quality of carbon disclosure is captured by employing content analysis based on Hrasky's (2011) symbolic and behavioral disclosure scale. Six categories were used to capture differences in the nature of disclosure, i.e. symbolic or behavioral. Appendix A shows the different categories.

All indices $(\mathrm{RMSEA}=0.000, \mathrm{SRMR}=0.000 \mathrm{CFI}=1, \mathrm{TLI}=1)$ show that path model has acceptable fit. The result showed no statistically significant relationship between quality of carbon disclosure and carbon performance, carbon legitimacy as well as economic performance. Likewise, no significant indirect relationship was found between quality of carbon disclosure and economic performance via carbon legitimacy. Hence, the findings indicate that voluntary carbon disclosure, irrespective of its quality and irrespective of firms' underlying carbon performance, enhances carbon (media) legitimacy and subsequently economic performance. Such findings are contrary to the desires of proponent of climate change.

ROE as an accounting-based measure was employed to capture economic performance. We repeat our path model using the market-based measure to ensure that findings are not a function of specific economic performance. Annual share return as a market-based measure is calculated as the natural logarithms of share prices at the end of the year divided by the price at the beginning of the year ${ }^{10}$. The overall model fit appears to be acceptable (RMSEA $=0.000, \mathrm{SRMR}=0.000 \mathrm{CFI}=1, \mathrm{TLI}=1$ ). The results remained unchanged after replacing ROE with annual share return. While no significant direct relationship was found between carbon performance and economic performance as well as carbon disclosure and economic performance, the results showed a strong and statistically significant indirect (via carbon (media) legitimacy) relationship between carbon disclosure and economic performance $(\beta=0.020$ and $p<.01)$. Finally, no significant indirect relationship was found between carbon performance and economic performance via carbon (media) legitimacy. 


\section{Discussion and conclusion}

Our primary goal in conducting this study was to investigate the direct and indirect (through legitimacy) effects of carbon performance and carbon disclosure on economic performance. This study extends the existing literature via investigating the direct and indirect (through (media) legitimacy) effect of carbon performance and carbon disclosure on economic performance. It also provides new evidence on the relationships between carbon performance, carbon disclosure, and economic performance through using the UK as a context.

Our path model's results showed several interesting findings. Based on balanced panel data of 95 UK firms over the period from 2009 to 2014 (total 475 observations), we found that carbon performance is not related to carbon disclosure. Furthermore, we found that while carbon (media) legitimacy is not influenced by carbon performance, carbon disclosure (irrespective of its quality) positively and significantly enhances firm's carbon legitimacy. This suggests that companies can improve their legitimacy and subsequently economic performance by disclosing more carbon information regardless of its quality and firm's underlying carbon performance. Such results are not considered as good news for proponents of improved corporate carbon performance. As noted by Hopwood (2009), while an increased level of voluntary environmental disclosure can have a constructive outcome, there is a risk that such voluntary disclosures, in the pursuit of legitimation, aim to create a positive impression of corporate activities without meaningful changes in corporate environmental performance. In this regard, disclosure is argued to be used as a tool to alter stakeholders' perceptions of companies' environmental actions instead of making sincere efforts to reduce harm to the environment (Gray et al., 1995; Neu et al., 1998; Aerts and Cormier, 2009). As such, companies may have the tendency to be involved in "green-washing" (Frost et al., 2005; Kolk et al., 2008; Andrew and Cortese, 2010) behavior, and use disclosure to promote a different image/reputation of the company.

The results also indicated a significant positive relationship between carbon legitimacy and corporate economic performance. Consistent with the resource-based view of legitimacy theory, carbon (media) legitimacy can be a valuable intangible asset that enhances the economic performance of firms. Positive (media) legitimacy may attract more customers, investors, public funds, and so forth which results in better economic performance.

The result that economic performance is not influenced by carbon performance does not support the argument that it pays to be green. However, it implies that the firms' economic performance is not negatively affected by carbon reduction activities, and improving corporate carbon performance does not come out of shareholders' pockets. Likewise, non-significant relationship between carbon disclosure and economic performance suggests that the stakeholders (e.g. customers, investors) do not value voluntary carbon disclosure or such information may not be sufficient to send a clear message to stakeholders. In other words, the result suggests that stakeholders may not be able to interpret the disclosed information regarding corporate carbon activities, and hence, decide not to value such information, or that they are able to understand it but they think it is not relevant, and hence decide not to attribute any value to it. This is consistent with Ilhan et al.'s (2019) findings that the vast majority of institutional investors believe that current qualitative and quantitative climate disclosures (i.e. carbon-related disclosure) are not precise and informative. They also believe that 'climate reporting should be mandatory and more standardized' (Ilhan et al., 2019, p.1). Hence, more comprehensive and mandatory regulations regarding carbon disclosure may enhance the interpretability and reliability of such disclosure and improve stakeholders' trust. Such results also confirm Kolk et al. (2008) findings that neither the level of carbon disclosure promoted by CDP nor the more detailed carbon accounting provides valuable information for investors, policymakers, and NGOs.

This study has several implications and recommendations for green stakeholders (e.g. green customers, investors), media, policy-makers, and corporate managers. The results showed that carbon (media) legitimacy is an important factor in enhancing corporate economic performance. However, since carbon performance is not reflected in carbon legitimacy, green customers and investors need to be cautious when making a decision and looking at the carbon performance of the firms rather than a good (media) legitimacy. Otherwise, managers may lose their incentives to improve a firms' carbon performance. The results also showed a certain degree of naivety on the part of the media in assessing corporate carbon behavior, since it values the carbon disclosure (irrespective of its quality) more than carbon performance. Such media behavior may hinder future improvement in the carbon performance of firms.

Since companies can improve their carbon (media) legitimacy by disclosing voluntary carbon information irrespective of its quality and underlying carbon performance, the message of the current study for policy-makers is that tougher regulation is needed on the part of voluntary carbon disclosure to prevent companies to take advantage of such voluntary disclosure. Finally, the recommendation of this study for corporate management is that pursuing carbon reduction activities to mitigate the impact of climate change does not happen at the expense of a firm's economic growth.

Like other studies, this study is subject to some limitations. First, this study as an archival study can merely provide evidence on relationships, but not causality (see e.g. Alewine, 2010; Cho et al., 2012). Second, the measure of carbon legitimacy may raise questions as it depends on the classification of newspaper articles to different categories which may differ between different individuals. In addition, this proxy merely captures media perceptions of corporate activities, not other stakeholders' perceptions. However, despite these limitations, it is encouraging that this study investigated the mediatory role of carbon (media) legitimacy in enhancing firms' economic performance. Finally, this study merely focused on relatively large UK companies (FTSE350) and hence it cannot be generalized to other contexts. Future research can employ the theoretical model of the current study for other developed or developing countries and compare their findings to see how different countries with different social, political, and cultural situations react to carbon and climate changerelated issues.

\section{References}

[1] Abdel-Maksoud, A., Jabbour, M., \& Abdel-Kader, M. (2020). Stakeholder pressure, eco-control systems, and firms' performance: empirical evidence from UK manufacturers. Accounting Forum, https://doi.org/10.1080/01559982.2020.1827697.

[2] Ader, C.R. (1995). A longitudinal study of agenda setting for the issue of environmental pollution. Journalism \& Mass Communication Quarterly, 72(2), 300-311. https://doi.org/10.1177/107769909507200204.

[3] Aerts, W., \& Cormier, D. (2009). Media legitimacy and corporate environmental communication. Accounting, Organization, and Society, 34(1), 127. https://doi.org/10.1016/j.aos.2008.02.005.

[4] Alewine, H.C. (2010). A model for conducting experimental environmental accounting research. Sustainability Accounting, Management and Policy Journal, 1(2), 256-291. https://doi.org/10.1108/20408021011089275.

[5] Al-Tuwaijri, S.A., Christensen, T.E., \& Hughes II, K. (2004). The relations among environmental disclosure, environmental performance, and economic performance: a simultaneous equations approach. Accounting. Organization. and Society, 29(5-6), 447-471. https://doi.org/10.1016/S0361-3682(03)00032-1.

[6] Anderson, D., Sweeney, D., Williams, T., Camm, J., \& Cochran, J. (2013). Statistics for business \& economics. Boston: Cengage Learning. 
[7] Andrew, J., \& Cortese, C. (2010). Greenhouse gas reporting and the Carbon Disclosure Project. Paper Presented at the Sixth Asia Pacific Interdisciplinary Research in Accounting (APIRA) Conference, Sydney, Australia. Available at: http://apira2010.econ.usyd.edu.au/conference_proceedings/APIRA-2010-080-Andrew-Greenhouse-gas-reporting-and-the-carbon-disclosureproject.pdf.

[8] Bansal, P., \& Clelland, I. (2004), Talking trash: Legitimacy, impression management, and unsystematic risk in the context of the natural environment. Academy of Management Journal, 47(1), 93-104. https://doi.org/10.2307/20159562.

[9] Baum, J.A.C., \& Powell, W.W. (1995). Cultivating an Institutional Ecology of Organizations: Comment on Hannan, Carroll, Dundon, and Torres. American Sociological Review, 60, 529-538. https://doi.org/10.2307/2096292.

[10] Berthelot, S., Coulmont, M. \& Serret, V. (2012). Do investors value sustainability reports? A Canadian study. Corporate Social Responsibility and Environmental Management, 19(6), 355-363. https://doi.org/10.1002/csr.285.

[11] Brinkman, M.W., Hoffman, N., \& Oppenheim, J.M. (2008). How climate change could affect corporate valuations. McKinsey Quarterly, 29 , 1-7.

[12] Busch, T., \& Hoffmann, V.H. (2011). How Hot Is Your Bottom Line? Linking Carbon and Financial Performance. Business and Society, 50(2), 233265. https://doi.org/10.1177/0007650311398780.

[13] Carbon Disclosure Project. Carbon Disclosure $\quad$ Project $2009 \quad$ Global http://www.sae.org/events/green/reference/2010/Carbon\%20Disclosure\%20Project\%202009\%20Global\%20500\%20Report.pdf/. Accessed [15.10.14].

[14] Chapple L., Clarkson P., \& Gold D. (2013). The cost of carbon: capital market effects of the proposed emission trading scheme (ETS). Abacus, 49(1), 1-33. https://doi.org/10.1111/abac.12006.

[15] Castelo Branco, M., \& Rodrigues, L.L. (2006). Corporate social responsibility and resource-based perspectives. Journal of Business Ethics, 69, 111132. https://doi.org/10.1007/s10551-006-9071-Z.

[16] Chen, M.C., Cheng, S.J., \& Hwang, Y. (2005). An empirical investigation of the relationship between intellectual capital and firms' market value and financial performance. Journal of intellectual capital, 6(2), 159-176. https://doi.org/10.1108/14691930510592771.

[17] Cho, C.H., Guidry, R.P., Hageman, A.M., \& Patten, D.M. (2012). Do actions speak louder than words? An empirical investigation of corporate environmental reputation. Accounting, Organization, and Society, 37, 14-25. https://doi.org/10.1016/j.aos.2011.12.001.

[18] Cho, C.H., \& Patten, D.M. (2007). The role of environmental disclosures as tools of legitimacy: A research note. Accounting, Organization, and Society, 32, 639-647. https://doi.org/10.1016/j.aos.2006.09.009.

[19] Cho, C.H., \& Roberts, R.W. (2010). Environmental reporting on the internet by America's Toxic 100: Legitimacy and self-presentation. International Journal of Accounting and Information Systems. 11(1), 1-16. https://doi.org/10.1016/i.accinf.2009.12.003.

[20] Clarkson, P.M., Li, Y., Pinnuck, M. and Richardson, G.D. (2015). The valuation relevance of greenhouse gas emissions under the European Union carbon emissions trading scheme. European Accounting Review, 24(3), 551-580. https://doi.org/10.1080/09638180.2014.927782.

[21] Clarkson, P.M., Li, Y., Richardson, G.D., \& Vasvari, F.P. (2008). Revisiting the relation between environmental performance and environmental disclosure: An empirical analysis. Accounting, Organization, and Society, 33(4-5), 303-327. https://doi.org/10.1016/j.aos.2007.05.003.

[22] Clarkson, P.M., Overell, M.B., \& Chapple, L. (2011). Environmental Reporting and its Relation to Corporate Environmental Performance. Abacus, 47(1), 27-60. https://doi.org/10.1111/j.1467-6281.2011.00330.x.

[23] Cormier, D., \& Magnan, M. (2015). The economic relevance of environmental disclosure and its impact on corporate legitimacy: An empirical investigation. Business Strategy and the Environment, 24(6), 431-450. https://doi.org/10.1002/bse.1829.

[24] Cotter, J., \& Najah, M.M. (2012). Institutional investor influence on global climate change disclosure practices. Australian Journal of Management, 37(2), 169-187. https://doi.org/10.1177/0312896211423945.

[25] Datt, R., Luo, L., and Tang, Q. (2019). The Impact of Legitimacy Threat on the Choice of External Carbon Assurance: Evidence from the United States. Accounting Research Journal (2019), 32(2), 181-202. https://doi.org/10.1108/ARJ-03-2017-0050.

[26] Deegan, C. (2002). Introduction: The legitimising effect of social and environmental disclosures - a theoretical foundation. Accounting, Auditing \& Accountability Journal, 15(3), 282-311. https://doi.org/10.1108/09513570210435852.

[27] Deegan, C., \& Unerman, J. (2011). Financial Accounting Theory. London: McGraw-Hill Education Publisher.

[28] Deephouse, D.L. (2000). Media Reputation as a Strategic Resource: An Integration of Mass Communication and Resource-Based Theories. Journal of Management, 26(6), 1091. https://doi.org/10.1177/014920630002600602.

[29] Deephouse, D.L., \& Carter, S.M. (2005), An Examination of Differences Between Organizational Legitimacy and Organizational Reputation. Journal of Management Studies, 42(2), 329-60. https://doi.org/10.1111/j.1467-6486.2005.00499.x.

[30] Delmas, M.A., \& Nairn-Birch, N.S. (2011). Is the Tail Wagging the Dog? An Empirical Aanalysis of Corporate Carbon Footprints and Financial Performance. Working Paper. UCLA Institute of the Environment and Sustainability Working Paper Series. University of California, Los Angeles.

[31] De Villiers, C., \& Van Staden, C.J. (2010). Shareholders' requirements for corporate environmental disclosures: A cross country comparison. The British Accounting Review, 42(4), 227-240. https://doi.org/10.1016/j.bar.2010.08.002.

[32] Fanelli, A., \& Misangyi, V.F. (2006), Bringing out charisma: CEO charisma and external stakeholders. The Academy of Management Review, 31(4), 1049-1061. https://doi.org/10.5465/amr.2006.22528170.

[33] Fombrun, C. J. (1996). Reputation: Realizing value from the corporate image. Boston, MA: Harvard Business School Press.

[34] Frost, G., Jones, S., Loftus, J., \& Laan, S. (2005), A survey of sustainability reporting practices of Australian reporting entities. Australian Accounting Review, 15(35), 89-96. https://doi.org/10.1111/j.1835-2561.2005.tb00256.x.

[35] Gallego-Alvarez, I. (2012). Impact of CO2 Emission Variation on Firm Performance. Business Strategy and the Environment, $21,435-454$. https://doi.org/10.1002/bse.1729.

[36] Gamson, W.A., Croteau, D., Hoynes, W., \& Sasson, T. (1992). Media images and the social construction of reality. Annual review of sociology, 18(1), 373-393. https://doi.org/10.1146/annurev.so.18.080192.002105.

[37] Giannarakis, G., Zafeiriou, E., \& Sariannidis, N. (2017). The impact of carbon performance on climate change disclosure. Business Strategy and the Environment, 26(8), 1078-1094. https://doi.org/10.1002/bse.1962.

[38] Gray, R., Kouhy, R., \& Lavers, S. (1995). Corporate social and environmental reporting: a review of the literature and a longitudinal study of UK disclosure. Accounting, Auditing \& Accountability Journal. 8(2), 47-77. https://doi.org/10.1108/09513579510146996.

[39] Green, W., and Zhou, S. (2013). An International Examination of Assurance Practices on Carbon Emissions Disclosures. Australian Accounting Review, 23(1), 54-66. https://doi.org/10.1111/j.1835-2561.2012.00186.x.

[40] Günther, E., Hoppe, H., \& Endrikat J., (2012), Corporate financial performance and corporate environmental performance: a perfect match? Zeitschrift für Umweltpolitik und Umweltrecht, 34, 279-296.

[41] Hair Jr, J.F., Black, W.C., Babin, B.J., \& Anderson, R.E. (2009). Multivariate Data Analysis. (7th edition). Prentice Hall, Upper Saddle River, NJ.

[42] Hahn, R., Reimsbach, D., \& Schiemann, F. (2015). Organizations, Climate Change, and Transparency: Reviewing the Literature on Carbon Disclosure. Organization and Environment, 28(1), 80-102. https://doi.org/10.1177/1086026615575542.

[43] Haque, F. (2017), The Effects of Board Characteristics and Sustainable Compensation Policy on Carbon Performance of UK Firms. The British Accounting Review, 49(3), 347-64. https://doi.org/10.1016/j.bar.2017.01.001.

[44] Hassan, A., \& Kouhy, R. (2014). Time-series cross-sectional environmental performance and disclosure relationship: specific evidence from a lessdeveloped country. International Journal of Accounting and Economics Studies, 2(2), 60-73. https://doi.org/10.14419/ijaes.v2i2.2748

[45] Hasseldine, J., Salama, A.I., \& Toms, J.S. (2005). Quantity versus quality: the impact of environmental disclosures on the reputations of UK Plcs. British Accounting Review, 37(2), 231-248. https://doi.org/10.1016/j.bar.2004.10.003.

[46] Hatakeda, T., Kokubu, K., Kajiwara, T., \& Nishitani, K. (2012), Factors influencing corporate environmental protection activities for greenhouse gas emission reductions: The relationship between environmental and financial performance. Environmental Resource Economics, 53, 455-481. https://doi.org/10.1007/s10640-012-9571-5. 
[47] Hopwood, A.G. (2009). Accounting and the environment. Accounting, Organization, and Society. 34(3-4), 433-439. https://doi.org/10.1016/j.aos.2009.03.002.

[48] Hörisch, J. (2013), Combating Climate Change through Organisational Innovation: An Empirical Analysis of Internal Emission Trading Schemes. Corporate Governance, 13(5), 569-582. https://doi.org/10.1108/CG-06-2013-0077.

[49] Hrasky, S. (2011). Carbon footprints and legitimation strategies: symbolism or action? Accounting, Auditing and Accountability Journal. 25(1), 174198. https://doi.org/10.1108/09513571211191798.

[50] Hu, L.T., \& Bentler, P.M. (1999). Cutoff criteria for fit indexes in covariance structure analysis: Conventional criteria versus new alternatives. Structural equation modeling: a multidisciplinary journal, 6(1), 1-55. https://doi.org/10.1080/10705519909540118.

[51] Hughes, S.B., Anderson, A., \& Golden, S. (2001). Corporate environmental disclosures: are they useful in determining environmental performance? Journal of Accounting and Public Policy, 20, 217-240. https://doi.org/10.1016/S0278-4254(01)00031-X.

[52] Hummel, K., \& Roetzel, P. (2019). Mandating the sustainability disclosure in annual reports - evidence from the United Kingdom. Schmalenbach Business Review, 71, 205-247. https://doi.org/10.1007/s41464-019-00069-8.

[53] Ilhan, E., Krueger, P., Sautner, Z. and Starks, L.T. (2019). Institutional investors' views and preferences on climate risk disclosure. Available at SSRN 3437178. https://doi.org/10.2139/ssrn.3437178.

[54] Iwata, H., \& Okada, K. (2011). How does environmental performance affect financial performance? Evidence from Japanese manufacturing firms. Ecological Economics, 70, 1691-1700. https://doi.org/10.1016/j.ecolecon.2011.05.010.

[55] Jones, P., Wynn, M., Hillier, D., \& Comfort, D. (2017), The sustainable development goals and information and communication technologies. Indonesian Journal of Sustainability Accounting and Management, 1(1), 1-15. https://doi.org/10.28992/ijsam.v1i1.22.

[56] Kalu, J.U., Buang, A. \& Aliagha, G.U. (2016). Determinants of voluntary carbon disclosure in the corporate real estate sector of Malaysia. Journal of environmental management, 182, pp.519-524. https://doi.org/10.1016/j.jenvman.2016.08.011.

[57] Kim, E., \& Lyon, T. (2011). When does institutional investor activism increase shareholder value?: the carbon disclosure project. The BE Journal of Economic Analysis and Policy,11(1), 1-27. https://doi.org/10.2202/1935-1682.2676.

[58] Kolk, A., Levy, D., \& Pinkse, J. (2008). Corporate responses in an emerging climate regime: The institutionalization and commensuration of carbon disclosure. European Accounting Review, 17(4), 719-745. https://doi.org/10.1080/09638180802489121.

[59] KPMG. 2013. The KPMG Survey of Corporate Responsibility Reporting 2013. Available at: https://assets.kpmg/content/dam/kpmg/pdf/2015/08/kpmg-survey-of-corporate-responsibility-reporting-2013.pdf. Accessed 15.10. 2020.

[60] Lee, S., Park, Y., \& Klassen R.D. (2015). Market Responses to Firms' Voluntary Climate Change Information Disclosure and Carbon Communication. Corporate Social Responsibility and Environmental Management, 22, 1-12. https://doi.org/10.1002/csr.1321.

[61] Lewandowski, S. (2017). Corporate Carbon and Financial Performance: The Role of Emission Reductions. Business Strategy and the Environment, 26, 1196-1211. https://doi.org/10.1002/bse.1978.

[62] Li, D., Huang, M., Ren, S., Chen, X., \& Ning, L. (2018). Environmental legitimacy, green innovation, and corporate carbon disclosure: Evidence from CDP China 100. Journal of Business Ethics, 150(4), 1089-1104. https://doi.org/10.1007/s10551-016-3187-6.

[63] Liao, L., Luo, L., \& Tang, Q. (2014). Gender diversity, board independence, environmental committee and greenhouse gas disclosure. British Accounting Review, 47, 409-424. https://doi.org/10.1016/j.bar.2014.01.002.

[64] Lindblom, C.K. (1994). The implications of organisational legitimacy for corporate social performance and disclosure, paper presented at the Critical Perspectives on Accounting Conference, New York, NY.

[65] Liu, Y.S., Zhou, X., Yang, J.H., \& Hoepner, A.G.F. (2016). Corporate Carbon Emission and Financial Performance: Does Carbon Disclosure Mediate the Relationship in the UK? Discussion Paper, Number: ICM-2016-03. ICMA Centre, Henley Business School, University of Reading. https://doi.org/10.2139/ssrn.2941123.

[66] Luo, L., \& Tang, Q. (2014). Does voluntary carbon disclosure reflect underlying carbon performance? Journal of Contemporary Accounting and Economics, 10(3), 191-205. https://doi.org/10.1016/j.jcae.2014.08.003.

[67] Luo, L., Lan, Y.C., \& Tang, Q. (2012). Corporate incentives to disclose carbon information: evidence from the CDP global 500 report. Journal of International Financial Management and Accounting, 23(2), 93-120 https://doi.org/10.1111/j.1467-646X.2012.01055.X

[68] Luo, L., Tang, Q., \& Lan, Y.C. (2013). Comparison of propensity for carbon disclosure between developing and developed countries: a resource constraint perspective. Accounting Research Journal, 26, 6-34. https://doi.org/10.1108/ARJ-04-2012-0024.

[69] Margolis, J.D., Elfenbein, H.A., \& Walsh, J.P. (2009). Does it pay to be good... and does it matter? A meta-analysis of the relationship between corporate social and financial performance. Available at SSRN: http://ssrn.com/abstract=1866371 https://doi.org/10.2139/ssrn.1866371.

[70] Mathur, S., \& Kenyon, A. (2008). Creating Valuable Business Strategies. Routledge. https://doi.org/10.4324/9780080942483.

[71] Matsumura, E.M., Prakash, R., \& Vera-Muño, S.C. (2014). Firm-Value Effects of Carbon Emissions and Carbon Disclosures. The Accounting Review, 89(2), 695-724. https://doi.org/10.2308/accr-50629.

[72] Meng, X.H., Zeng, S.X., Shi, J.J., Qi, G.Y. \& Zhang, Z.B. (2014). The relationship between corporate environmental performance and environmental disclosure: An empirical study in China. Journal of environmental management, 145, 357-367. https://doi.org/10.1016/j.jenvman.2014.07.009.

[73] Michelon, G., Pilonato, S., \& Ricceri, F. (2015). CSR reporting practices and the quality of disclosure: An empirical analysis. Critical Perspectives on Accounting, 33, 59-78. https://doi.org/10.1016/j.cpa.2014.10.003.

[74] Moneva, J.M., \& Ortas, E. (2010). Corporate environmental and financial performance: a multivariate approach. Industrial Management and Data Systems, 110(2), 193-210. https://doi.org/10.1108/02635571011020304.

[75] Neu, D., Warsame, H., \& Pedwell, K. (1998). Managing Public Impressions: Environmental Disclosures in Annual Reports. Accounting, Organizations and Society, 23(3), 265-282. https://doi.org/10.1016/S0361-3682(97)00008-1.

[76] Ngwakwe, C.C., \& Msweli, P. (2013). On carbon emission reduction and firm performance: example from 3M Company. Environmental Economics, $4(2), 54-61$.

[77] Okereke, C. (2007). An exploration of motivations, drivers and barriers to carbon management: the UK FTSE 100. European Management Journal, 25, 475-486. https://doi.org/10.1016/j.emj.2007.08.002.

[78] Patten, D.M. (2002). The relation between environmental performance and environmental disclosure: a research note. Accounting, Organization, and Society, 27(8), 763-773. https://doi.org/10.1016/S0361-3682(02)00028-4.

[79] Qian, W., \& Schaltegger, S. (2017). Revisiting carbon disclosure and performance: Legitimacy and management views. The British Accounting Review, 49(4), 365-379. https://doi.org/10.1016/j.bar.2017.05.005.

[80] Renukappa, S., Akintoye, A., Egbu, C., \& Goulding, J. (2013). Carbon Emission Reduction Strategies in the UK Industrial Sectors: An Empirical Study. International Journal of Climate Change Strategies and Management, 5(3), 304-23. https://doi.org/10.1108/IJCCSM-02-2012-0010.

[81] Roberts, P.W., \& Dowling, G.R. (2002). Corporate Reputation and Sustained Superior Financial Performance. Strategic Management Journal, 23, 1077-1093. https://doi.org/10.1002/smj.274.

[82] Rokhmawati, A., \& Gunardi, A. (2017), Is going green good for profit? Empirical evidence from listed manufacturing firms in Indonesia. International Journal of Energy Economics and Policy, 7(4), 181-192.

[83] Rokhmawati, A., Sathye, M., \& Sathye, S. (2015), The effect of GHG emission, environmental performance, and social performance on financial performance of listed manufacturing firms in Indonesia. Procedia Social and Behavioral Sciences, 211, 461-470. https://doi.org/10.1016/j.sbspro.2015.11.061.

[84] Russo, M., \& Minto, A. (2012), Competitive strategy and the environment: a field of inquiry emerges. In The Oxford Handbook of Business and the Natural Environment, Bansal P., and Hoffman A.J. (eds). Oxford University Press: New York; 29-49. https://doi.org/10.1093/oxfordhb/9780199584451.003.0002.

[85] Saka, C., \& Oshika, T. (2014). Disclosure effects, carbon emissions and corporate value. Sustainability Accounting, Management and Policy Journal, 5(1), 22-45. https://doi.org/10.1108/SAMPJ-09-2012-0030. 
[86] Schumacker, R. E., \& Lomax, R. G. (2004). A beginner's guide to structural equation modeling. Mahwah, NJ: Lawrence Erlbaum Associates. https://doi.org/10.4324/9781410610904.

[87] Sharfman, M. P., \& Fernando, C.S. (2008). Environmental risk management and the cost of capital. Strategic Management Journal, 29, 569-592. https://doi.org/10.1002/smj.678.

[88] Slawinski, N., Pinkse, J., Busch, T., \& Banerjee, SB. (2015). The role of short-termism and uncertainty avoidance in organizational inaction on climate change a multi-level framework. Business and Society, 56(2): 253-282. https://doi.org/10.1177/0007650315576136.

[89] Stolowy, H. (2017). Letter from the Editor: Why Are Papers Desk Rejected at European Accounting Review? European Accounting Review, 26(3), 411-418. https://doi.org/10.1080/09638180.2017.1347360.

[90] Wang, L., Li, S., \& Gao, S. (2014), Do Greenhouse Gas Emissions Affect Financial Performance? An Empirical Examination of Australian Public Firms. Business Strategy and the Environment, 23, 505-519. https://doi.org/10.1002/bse.1790.

[91] Weber, R.P. (1990). Basic Content Analysis. 2 edition ed. Thousand Oaks: Sage Publications Ltd. https://doi.org/10.4135/9781412983488.

[92] West, S. G., Finch, J. F., \& Curran, P. J. (1995). Structural equation models with non-normal variables: Problems and remedies. In R. Hoyle (Ed.), Structural equation modeling: Concepts, issues and applications (56-75). Newbury Park, CA: Sage.

[93] Woodward, D.G., Edwards, P., \& Birkin, F. (1996). Organizational Legitimacy and Stakeholder Information Provision 1. British Journal of Management, 7(4), 329-347. https://doi.org/10.1111/j.1467-8551.1996.tb00123.x.

\section{Appendix a: the disclosure categories}

\begin{tabular}{|c|c|c|}
\hline $\begin{array}{l}\text { Symbolic Dis- } \\
\text { closure }\end{array}$ & Description & Exemplifying disclosure \\
\hline $\begin{array}{l}\text { Normative } \\
\text { statement }\end{array}$ & $\begin{array}{l}\text { Statements espousing } \\
\text { commitment to and recognition of the importance of } \\
\text { carbon footprints, global warming, and climate } \\
\text { change but not indicative of specific action or out- } \\
\text { come }\end{array}$ & $\begin{array}{l}\text { We believe it is important for Australia to establish a long-term green- } \\
\text { house gas emissions reduction goal and to map a path to achieve it. } \\
\text { Climate change and resource scarcity are issues that require us to evolve } \\
\text { our business model to meet our responsibilities. }\end{array}$ \\
\hline $\begin{array}{l}\text { Aspirational } \\
\text { target }\end{array}$ & $\begin{array}{l}\text { Articulation of targets or } \\
\text { objectives to be achieved in the future without an as- } \\
\text { sociated action }\end{array}$ & $\begin{array}{l}\text { Our ultimate goal is to have no carbon emissions released into the atmos- } \\
\text { phere. } \\
\text { We have set targets for paper use, recycling facilities, and greenhouse gas } \\
\text { emissions. }\end{array}$ \\
\hline $\begin{array}{l}\text { Awards/recog- } \\
\text { nition }\end{array}$ & $\begin{array}{l}\text { Statements indicating external recognition of positive } \\
\text { efforts pertinent to carbon footprints, } \\
\text { global warming and climate change }\end{array}$ & $\begin{array}{l}\text { We were included in the } 2004 \text { Climate Leadership Index comprising the } \\
50 \text { "best-in-class" responses. }\end{array}$ \\
\hline $\begin{array}{l}\text { Behavioral } \\
\text { Disclosure }\end{array}$ & Description & Exemplifying disclosure \\
\hline $\begin{array}{l}\text { Internal activi- } \\
\text { ties }\end{array}$ & $\begin{array}{l}\text { Statements about specific internal corporate actions } \\
\text { taken relevant to carbon footprints, global warming, } \\
\text { and climate change }\end{array}$ & $\begin{array}{l}\text { Where possible we install electricity generators that use the waste gas as } \\
\text { fuel, electricity produced in this way actually reduces greenhouse gas } \\
\text { emissions. } \\
\text { The } \$ \text { A } 30 \text { million plant that we opened in September will generate ap- } \\
\text { proximately six megawatts of electricity per hour and reduce greenhouse } \\
\text { gas emissions by } 250,000 \text { tons of carbon dioxide equivalent per year. }\end{array}$ \\
\hline $\begin{array}{l}\text { External activi- } \\
\text { ties }\end{array}$ & $\begin{array}{l}\text { Statements about involvement in activities relevant } \\
\text { to carbon footprints, global warming, and climate } \\
\text { change that are initiatives developed with partners or } \\
\text { projects external to the organization }\end{array}$ & $\begin{array}{l}\text { Since becoming a member of the Greenhouse Challenge Program one di- } \\
\text { vision has completed a range of efficiency improvement projects resulting } \\
\text { in reduced greenhouse gas emissions of more than one million tons per an- } \\
\text { num. } \\
\text { To support efforts to research the impacts of climate change we have part- } \\
\text { nered with the EarthWatch Institute to offer an opportunity for our co- } \\
\text { workers to join an international conservation research project. }\end{array}$ \\
\hline Assisting others & $\begin{array}{l}\text { Statements about actions taken to help others to re- } \\
\text { duce their carbon footprint }\end{array}$ & $\begin{array}{l}\text { We have developed a range of products so customers have a choice about } \\
\text { their contribution to greenhouse gas emissions reduction. } \\
\text { All colleagues who are allocated car space for non-company vehicles are } \\
\text { required to offset their annual greenhouse gas emissions through a sub- } \\
\text { scription to GreenFleet. }\end{array}$ \\
\hline
\end{tabular}

Source: Hrasky (2011, p. 184). 